\title{
Incidence, Spatial Patterns, and Associations Among Viruses in Snap Bean and Alfalfa in New York
}

\author{
Denis A. Shah, Helene R. Dillard, Sudeshna Mazumdar-Leighton, and Dennis Gonsalves, Department of Plant \\ Pathology, and Brian A. Nault, Department of Entomology, New York State Agricultural Experiment Station, Ge- \\ neva 14456
}

\begin{abstract}
Shah, D. A., Dillard, H. R., Mazumdar-Leighton, S., Gonsalves, D., and Nault, B. A. 2006. Incidence, spatial patterns, and associations among viruses in snap bean and alfalfa in New York. Plant Dis. 90:203-210.

Recent epidemics in snap bean (Phaseolus vulgaris) characterized by virus-like symptoms prompted a survey of commercial fields for Alfalfa mosaic virus (AMV), Cucumber mosaic virus (CMV), and the Bean yellow mosaic virus (BYMV)/Clover yellow vein virus (ClYVV) complex in 2002 and 2003. Snap bean fields were either remote from or adjacent to alfalfa (Medicago sativa), a putative source of these viruses. Bean fields were sampled at the bloom stage in both years. Model-adjusted mean incidences of infection by AMV, BYMV/ClYVV, and CMV were 41.96, 6.56, and 6.69\%, respectively, in alfalfa, and 6.66, 6.38, and $17.20 \%$ in snap bean. In 2002, $25.9 \%$ of snap bean plants were infected by more than one virus; $<1 \%$ had more than one virus in 2003. Virus incidences did not differ between snap bean adjacent to or remote from alfalfa, but incidence of infection by AMV and BYMV/CIYVV was significantly higher in snap bean planted later in the season rather than earlier. In 2002, there was a positive association between AMV and CMV in the tendency to find both viruses in the same snap bean plant. In some years, infection by aphid-transmitted viruses can become widespread in snap bean in New York.
\end{abstract}

Additional keywords: quadrat sampling, virus epidemiology

Beginning in 2000, snap bean (Phaseolus vulgaris L.) crops exhibiting virus-like symptoms on the foliage (leaf distortion, yellow and green mottling, and mosaic) were increasing in frequency on a regional scale across the northern United States and Canada $(10,20)$. These crops also produced fewer pods or pods that were either twisted or necrotic (hence unmarketable). Across the Midwest and northeastern United States in 2001, virus infection in some late-season processing snap bean fields resulted in total yield loss (20). High temperature stress in snap bean during reproductive development can cause floral abscission (33), resulting in reduced pod number. High temperatures also disrupt fertilization and ovule development, which then leads to deformed pods because of

Corresponding author: D. A. Shah

E-mail: das28@cornell.edu

Current address of S. Mazumdar-Leighton: Department of Botany, Delhi University, Delhi, India.

Current address of D. Gonsalves: United States Department of Agriculture-Agricultural Research Service, PWA, Pacific Basin Agricultural Research Center, Hilo, HI 96720.

Accepted for publication 8 September 2005.

DOI: 10.1094/PD-90-0203

(C) 2006 The American Phytopathological Society reduced seed set (36). However, the combination of virus-like symptoms, presence of soybean aphid (Aphis glycines Matsumura) at sometimes high numbers, and positive serological assays from affected fields strongly suggested that the observed symptoms and yield losses represented an emerging problem of virus epidemics, which had been less severe in past decades (37).

The most prevalent viruses found in preliminary serological assays of snap bean samples from New York in 2001 were Alfalfa mosaic virus (AMV), Cucumber mosaic virus (CMV), and the Potyvirus genus (10). AMV, CMV, and members of the Potyvirus genus are transmitted by several species of aphids in a nonpersistent, stylet-borne manner (32). If aphids are primarily responsible for spreading these viruses into snap bean fields, a likely virus source is alfalfa (Medicago sativa L.). Alfalfa dominates the central and western New York agricultural landscape, where snap bean production is also concentrated, and is a reservoir of several viruses (46), some of which are transmissible to bean (4). Alfalfa fields typically remain in production for 4 to 6 years, sometimes longer, but virus incidence in forages tends to fluctuate over time and location, either increasing or decreasing $(7,41)$.

Studies on virus spread have demonstrated gradients in the incidences of aphid-transmitted viruses in legumes when grown near to virus-infected forages $(13,17)$. Another study focusing on aphid movement showed that densities of the pea aphid (Acyrthosiphon pisum (Harris)) alatae in a lima bean field increased immediately after a nearby alfalfa field was harvested, suggesting that the aphid migrated from alfalfa to the lima beans (23). An increase in the densities of $A$. pisum alatae was observed in dry bean fields immediately after adjacent alfalfa fields were harvested (45). Therefore, proximity to alfalfa could significantly increase the risk of virus infection in snap bean.

Our first objective was to survey commercial alfalfa and snap bean fields in New York for the incidences of the aphidtransmitted viruses AMV, CMV, and Bean yellow mosaic virus (BYMV). Alfalfa is a host to AMV (46) and BYMV (30). To our knowledge, commercial alfalfa fields in New York have not been surveyed previously for CMV; however, in a previous study, an isolate of CMV from alfalfa was infectious to bean (8). Aphid involvement in the transmission of viruses may be reflected by aggregated patterns of diseased plants (27). Therefore, our second objective was to quantify the spatial patterns of virus-infected plants in the same alfalfa and snap bean fields. The third objective was to determine whether virus incidence in snap beans depended on (i) the proximity of the snap bean field to alfalfa and (ii) planting time during the season. The time of arrival of aphid vectors can vary within a season; therefore, plantings made at different times in the season may be at different risks to virus infection (16). A fourth objective was to determine whether there were positive associations among the viruses in terms of their presence in infected plants.

\section{MATERIALS AND METHODS}

Field descriptions. Processing snap bean fields in Genesee, Niagara, and Orleans Counties in western New York were sampled in 2002 and 2003 (Table 1). Most fields were planted to the cv. Hystyle. Other fields were planted to the cvs. Igloo, Zeus, a mixture of Solei and Masai, Labrador, Summit, Hercules, and one freshmarket cultivar (Storm). The mean field size was 13.9 ha (range 3.8 to 23.7 ha) and fields typically bordered woods, corn, wheat, cabbage, and orchards. Six early- 
planted and six late-planted snap bean fields were sampled each year. Early plantings occurred from late May through the end of the first week of June, whereas late plantings occurred during the first 3 weeks of July. Three of the fields in each planting bordered an alfalfa field, whereas the other three were located $>1 \mathrm{~km}$ away from all leguminous crops. Alfalfa typically bordered only the west side of the snap bean fields, with the exception of two locations in 2002 and one location in 2003. Alfalfa fields averaged 12.1 ha in size (range from 3.0 to 27.9 ha) and most had been in production for 4 to 6 years.

Sampling and virus assays. Alfalfa fields were sampled within 2 weeks of snap bean emergence. Eighty plants were sampled per field in both years using quadrat sampling (26) (2002: 20 quadrats, four adjacent plants per quadrat; 2003: 16 quadrats, five adjacent plants per quadrat). Quadrats were selected arbitrarily within fields. Alfalfa fields had not been cut or harvested before sampling early in the season, whereas one cutting preceded all late-season samples. Snap bean fields were sampled (16 quadrats per field, five adjacent plants per quadrat) when they were at the bloom stage. Samples (consisting of whole plants) were kept in ice-packed coolers while being transported back to the laboratory.

Commercial bean cultivars exhibit different symptoms in response to infection by the same virus (10). Also, virus-infected alfalfa can remain asymptomatic (9). Therefore, identification of viruses in these crops is difficult without the aid of serological or molecular diagnostics. Snap bean and alfalfa plants were tested for the presence of AMV and CMV by enzymelinked immunosorbent assay (ELISA; 6) based on the double-antibody sandwich protocol using commercially available antibodies (Bioreba, Switzerland). We also assayed the samples by ELISA with commercial BYMV antibodies (Sanofi, France). However, we later learned that Clover yellow vein virus (ClYVV), which also is found in snap bean $(18,19)$ and alfalfa (30), cross-reacts serologically with BYMV (44). Therefore, we conservatively refer to any test positives as members of a BYMV/ClYVV complex. Antibodies, conjugates, and reagents were used in accordance with the manufacturers' recommendations, with the following modifications. To minimize nonspecific positive ELISA reactions, plates were blocked before the conjugation step with $1 \%$ (wt/vol) nonfat powdered milk in $1 \times$ phosphatebuffered saline ( $\mathrm{pH}$ 7.4) containing Tween 20 (0.5 ml/liter). Healthy and infected tissues supplied by the same manufacturers were included as controls on each plate. A sample was considered positive for the virus being tested if ELISA absorbance readings $(405 \mathrm{~nm})$ were at least three times that of the mean of the negative controls. All alfalfa and snap bean plants were tested individually for virus presence.
Molecular confirmation of AMV and CMV. Ten ELISA-positive plants were selected arbitrarily from snap bean and alfalfa fields in 2002 (CY1, Kelsey, Kludt, McCollum1, and Sentiff). Immunocapture reverse-transcriptase polymerase chain reaction (IC RT-PCR) was done using oligonucleotide primers encoding the AMV coat protein CPAMVfp: 5'TCCATCATGAGTTCTTCAC3' and CPAMVrp: 5'AGGACTTCATACCTTGACC3' (34), and the CMV coat protein gene fragment, KOR-RP: 5'AACACGGATTCAAACTGG3' and KOR-FP: 5'GAGTCATGGACAAATCTG3' (5). Virus-free greenhouse-grown plants were used as negative controls. The antisera used for immunocapture were the same as those used for ELISA. Immunocapture and virion release steps followed exactly a previously published protocol (21) except that RT-PCR was performed with a GeneAmp RNA PCR kit (Applied Biosystems, Foster City, CA) according to the manufacturer's instructions. The amplification regime for each virus consisted of 1 cycle at $94^{\circ} \mathrm{C}$ for $2 \mathrm{~min}$ followed by 35 cycles of denaturation at $94^{\circ} \mathrm{C}$ for $1 \mathrm{~min}$, primer annealing at $55^{\circ} \mathrm{C}$ for $1 \mathrm{~min}$, and extension at $72^{\circ} \mathrm{C}$ for 2 min on a PTC-100 HB thermocycler (MJ Research Inc., Boston). A final cycle of extension at $72^{\circ} \mathrm{C}$ for $5 \mathrm{~min}$ also was included. The amplification products were visualized by $1.5 \%$ agarose gel electrophoreses and standard ethidium bromide staining (42).

Table 1. Incidence and spatial patterns of viruses in snap bean plants sampled at the bloom stage in 2002 and $2003^{\mathrm{a}}$

\begin{tabular}{|c|c|c|c|c|c|c|c|c|c|}
\hline Year, field & Cultivar & Date planted & Class $^{b}$ & $\begin{array}{l}\text { Proximity } \\
\text { to alfalfa }\end{array}$ & $\begin{array}{c}\text { Sampling } \\
\text { date }\end{array}$ & AMV & BYMV/CIYVV & CMV & Any \\
\hline \multicolumn{10}{|l|}{2002} \\
\hline CY1 & Storm & 07 June & Early & Adjacent & 19 July & 12.6 & 5.0 & 14.4 & $19.4 *$ \\
\hline McCollum1 & Zeus & 26 May & Early & Adjacent & 12 July & 3.8 & 0.0 & 33.5 & 33.5 \\
\hline Torrey $^{\mathrm{d}}$ & $\ldots$ & $\ldots$ & Early & Adjacent & 05 July & $24.9^{*}$ & $31.7 *$ & 25.8 & 61.4 \\
\hline Kludt & Hystyle & 02 June & Early & Remote & 19 July & 17.5 & 0.0 & $27.5 *$ & 33.8 \\
\hline Mill & Hystyle & 06 June & Early & Remote & 19 July & 15.0 & 10.0 & 32.5 & $40.0 *$ \\
\hline $\operatorname{Mix}^{\mathrm{d}}$ & r & & Early & Remote & 05 July & $22.5^{*}$ & 3.8 & 30.0 & 41.3 \\
\hline CY2 & Labrador & 12 July & Late & Adjacent & 23 August & $15.9^{*}$ & 38.3 & $39.3 *$ & 62.6 \\
\hline McCollum2 & Hercules & 02 July & Late & Adjacent & 15 August & $44.5^{*}$ & 10.0 & $61.0 *$ & 66.6 \\
\hline Oak-Ala & Hystyle & 20 July & Late & Adjacent & 29 August & 37.9 & 21.9 & 53.6 & 66.5 \\
\hline Kelsey & Igloo & 15 July & Late & Remote & 29 August & $35.0^{*}$ & 20.0 & 52.5 & $65.0 *$ \\
\hline $\mathrm{MB}$ & Igloo & 07 July & Late & Remote & 23 August & 32.5 & 12.5 & 33.8 & 56.3 \\
\hline Sentiff & Hystyle & 04 July & Late & Remote & 15 August & 50.0 & 43.8 & 85.0 & 88.8 \\
\hline \multicolumn{10}{|l|}{2003} \\
\hline Buck & Hystyle & 04 June & Early & Adjacent & 14 July & 0.8 & 1.7 & 42.5 & 44.2 \\
\hline $\mathrm{MC}$ & Hystyle & 03 June & Early & Adjacent & 14 July & $1.2 *$ & 3.7 & $13.8 *$ & 18.7 \\
\hline WCH & Hystyle & 27 May & Early & Adjacent & 08 July & 0.0 & 0.0 & 0.0 & 0.0 \\
\hline BAT & Hystyle & 30 May & Early & Remote & 14 July & 1.3 & 1.3 & $8.8^{*}$ & $10.0^{*}$ \\
\hline Gaines & Hystyle & 29 May & Early & Remote & 08 July & 0.0 & 0.0 & 0.0 & 0.0 \\
\hline Wood & Hystyle & 04 June & Early & Remote & 14 July & 0.0 & 0.0 & $28.8^{*}$ & $28.8 *$ \\
\hline Asbury & Solei and Masai & 03 July & Late & Adjacent & 14 August & 0.5 & 4.1 & 2.0 & 6.1 \\
\hline NB & Igloo & 18 July & Late & Adjacent & 21 August & 4.2 & 6.1 & 3.9 & 14.2 \\
\hline Orch & Hystyle & 15 July & Late & Adjacent & 21 August & 1.3 & $8.0^{*}$ & 2.5 & 11.8 \\
\hline Crick & Hystyle & 16 July & Late & Remote & 21 August & 3.8 & $10.0^{*}$ & $13.8 *$ & $23.8 *$ \\
\hline Perry & Solei and Masai & 03 July & Late & Remote & 14 August & 0.0 & 6.3 & 1.3 & 7.5 \\
\hline YG & Summit & 10 July & Late & Remote & 21 August & 5.0 & 10.0 & 3.8 & 17.5 \\
\hline
\end{tabular}

a $\mathrm{AMV}=$ Alfalfa mosaic virus, BYMV/CIYVV = Bean yellow mosaic virus or Clover yellow vein virus, $\mathrm{CMV}=$ Cucumber mosaic virus, any $=$ infection by any of these viruses. Asterisks indicate situations where the binary form of the index of dispersion $(D)$ is significantly greater than $1(P<0.05)$, indicating an aggregated pattern of virus infected plants (25).

${ }^{\mathrm{b}}$ Fields were classified as early-planted if sown between late May and the first week in June and late-planted if sown during the first 3 weeks of July.

${ }^{\mathrm{c}}$ Snap bean fields were either adjacent to an alfalfa field or $>1 \mathrm{~km}$ from the nearest alfalfa field (remote).

${ }^{\mathrm{d}}$ Cultivar and exact planting date were not available. 
The 750-bp amplification products from an infected alfalfa (NY-A) and a snap bean (NY-B) plant were cloned into TOPO TA cloning vectors according to the manufacturer's instructions (Invitrogen Corp., Carlsbad, CA). Six clones containing a 750-bp insert (three from NY-A and three from NY-B) were sequenced on both strands using universal M13 forward and reverse primers at the NYSAES Sequencing Facility, Geneva, NY. The AMV coat protein (cp) gene sequences along with predicted amino acid sequences were compared with accessions in the GenBank database using BLAST similarity searches (2).

Estimating virus incidence. Incidence of infection in alfalfa and in snap bean was estimated by $\hat{p}_{X}=x / N$, where $x$ is the number of plants positive for virus $X$, and $N$ is the number of plants sampled $(N=80$ per field in our study). If no virus-infected plants are recovered in an assay it does not mean that the incidence of infection is zero, because sampling could have missed infected plants when incidence is very low. If infected plants are assumed to be randomly distributed (not unreasonable when incidence is very low), then a $95 \%$ confidence interval upper limit for $\hat{p}_{X}$ (i.e., $\left.\hat{p}_{X, u}\right)$ is given by (26)

$\hat{p}_{X, u}=1-0.05^{(1 / N)}$

For the situations in which the virus was not detected in the given assay, the estimate of $\hat{p}_{X, u}$ was 0.037 , which means that, at the $95 \%$ probability level, the incidence of virus infection was less than $3.7 \%$.

Spatial pattern analysis. Quadrat sampling provides data in a form amenable to spatial pattern analysis of the incidence of virus-infected plants (25). Counts of the number of plants per quadrat positive for a given virus were used to calculate the binary form of the index of dispersion $(D)$ (15). The index is a measure of whether the variance in the number of infected plants per quadrat is greater than that expected assuming infected plants are randomly distributed throughout the sampled field. If the occurrence of infected plants within a field is random, then $D=1$. If $D>$ 1 , infected plants may be spatially aggregated, and one can test statistically the deviation of the observed $D$ from its expected value assuming a random spatial distribution (25).

Planting time and proximity to alfalfa effects on virus incidence in snap bean. In each year, snap bean fields were classified according to planting time (pt; early or late) and proximity to alfalfa (prox; adjacent or remote). Incidence of infection by AMV, BYMV/CIYVV, CMV, or by any of these viruses was considered as the dependent variable and pt and prox as independent variables. Data were analyzed using a generalized linear mixed model accounting for the binomial properties of the dependent variable (22), with pt and prox as fixed effects in a two-way factorial. Year and snap bean field were modeled as random effects. The variance due to subsampling within fields (i.e., quadrats) was included in the model's covariance structure (28). We used the SAS glimmix macro (SAS Institute, Cary, NC) to model the data.

Virus incidence in alfalfa. A similar statistical model to the one described above was used in relating the incidence of viruses to sampling year, but with modifications. In this instance, we fit an intercept-only term for fixed effects, with year and alfalfa field as random effects.

Correlation between virus incidence in adjacent alfalfa and snap bean fields. If proximity to alfalfa increases the risk of virus transmission by aphids to snap bean, then one may expect some correlation between virus incidence in adjacent snap bean and alfalfa fields. Virus incidence data for the 12 pairs of adjacent alfalfa and snap bean fields sampled over the 2 years were analyzed for correlations using Proc Corr of SAS. Both the Pearson coefficient and Spearman's coefficient were calculated.
Virus associations. Within a field, it was assumed that the distribution of the number of viruses per plant $(0,1,2$, or 3 viruses per plant) is described by a binomial probability distribution if the number of viruses per plant is random (i.e., there is no tendency for virus $X$ to be found concurrent with virus $Y$ in the same plant). As a preliminary analysis of possible associations among viruses within individual plants, $D$ was calculated for the distribution of the number of viruses per plant in each sampled field. Tests of whether $D>1$ were done as described above.

Data were examined further for pairwise associations among viruses in two ways. First, the no three-factor interaction loglinear model (1) was fit to the counts of virusinfected plants in a given field. This model is specified as

$$
\begin{aligned}
& \log \mu_{i j \mathrm{k}}=\lambda+\lambda_{i}^{\mathrm{AMV}}+\lambda_{j}^{\mathrm{CMV}} \\
& +\lambda_{k}^{\mathrm{BYMV} / \mathrm{CIYVV}}+\lambda_{i j}^{\mathrm{AMVCMV}} \\
& +\lambda_{i k}^{\mathrm{AMVBYMV} / C I Y V V}+\lambda_{j k}^{\mathrm{CMVBYMV} / C I Y V V}
\end{aligned}
$$

where $\mu_{i j k}$ is the expected frequency, the $\lambda_{a}^{X}$ are parameters for the effects of virus

Table 2. Incidence and spatial patterns of viruses in alfalfa fields, 2002 and $2003^{\mathrm{a}}$

\begin{tabular}{lcccc}
\hline & \multicolumn{4}{c}{ Incidence (\%) of plants with } \\
\cline { 2 - 5 } Year, field & AMV & BYMV/CIYVV & CMV & Any \\
\hline 2002 & & & & \\
CY1 & 87.5 & 35.0 & $8.8^{*}$ & 91.3 \\
CY2 & 90.0 & 10.0 & 26.3 & 93.8 \\
Kludt & $40.0^{*}$ & $\ldots$ b & $18.8^{*}$ & $48.8^{*}$ \\
McCollum1 & 46.3 & 12.5 & 30.0 & 68.8 \\
McCollum2 & 90.0 & 11.3 & 22.5 & 93.8 \\
Oak-Ala & 17.5 & 20.0 & 15.0 & 40.0 \\
Sentiff & $21.5 *$ & 19.0 & 21.5 & 49.4 \\
Torrey & 93.8 & 26.3 & 5.0 & 93.8 \\
2003 & & & & \\
Asbury & 11.3 & 0.0 & 0.0 & 11.3 \\
Buck & 95.0 & 0.0 & 0.0 & 95.0 \\
MC & 3.8 & 1.3 & 0.0 & 5.0 \\
NB & 3.8 & 0.0 & 0.0 & 3.8 \\
Orch & 2.5 & 13.8 & 5.0 & 20.0 \\
WCH & 58.8 & 6.3 & $72.5^{*}$ & 100 \\
\hline
\end{tabular}

${ }^{\mathrm{a}} \mathrm{AMV}=$ Alfalfa mosaic virus, $\mathrm{BYMV} / \mathrm{ClYVV}=$ Bean yellow mosaic virus or Clover yellow vein virus, $\mathrm{CMV}=$ Cucumber mosaic virus, any $=$ infection by any of these viruses. Asterisks indicate situations where the binary form of the index of dispersion $(D)$ is significantly greater than $1(P<$ 0.05 ), indicating an aggregated pattern of virus infected plants (25).

${ }^{\mathrm{b}} \mathrm{BYMV/ClYVV}$ was not assayed for in samples from the Kludt field. Incidence is for AMV, CMV or both viruses (any) in this field.

Table 3. Mean and associated variances in the incidence of virus infection in alfalfa fields in 2002 and 2003

\begin{tabular}{lcccc}
\hline & \multicolumn{4}{c}{ Covariance parameter estimates $^{\mathbf{a}}$} \\
\cline { 2 - 5 } Virus $^{\mathbf{b}}$ & Incidence (\%) $^{\mathbf{c}}$ & Year & Field & Quadrat \\
\hline AMV & 41.96 & 1.596 & 4.245 & 1.375 \\
BYMV/ClYVV & 6.56 & 2.509 & 0.909 & 0.828 \\
CMV & 6.69 & 1.891 & 3.099 & 0.997 \\
Any & 65.57 & 0.791 & 5.912 & 1.109 \\
\hline
\end{tabular}

${ }^{a}$ Model-based estimates of the variance in virus incidence between the 2 years, among fields, and among quadrats within fields.

${ }^{\mathrm{b}} \mathrm{AMV}=$ Alfalfa mosaic virus; $\mathrm{BYMV/CIYVV} \mathrm{=} \mathrm{Bean} \mathrm{yellow} \mathrm{mosaic} \mathrm{virus,} \mathrm{Clover} \mathrm{yellow} \mathrm{vein} \mathrm{virus,}$ or both; $\mathrm{CMV}=$ Cucumber mosaic virus; and any = infection by any of the aforementioned viruses.

${ }^{\mathrm{c}}$ Model-adjusted (accounting for the variances due to year, field, and quadrat) estimates of the incidence of virus-infected plants. 
$X$, and the $\lambda_{a b}^{X Y}$ specify the conditional dependence of virus $X$ and virus $Y$. If two viruses $X$ and $Y$ are conditionally independent, then $\lambda_{a b}^{X Y}=0$. However, there can be a strong effect of sample size on the inferential procedure, and confidence intervals provide a more useful way of assessing the relevance of any associations (1). The $95 \%$ confidence intervals (CI) were calculated for each pairwise interaction parameter, where possible. If the CI includes zero, there is no evidence of association between the viruses. In the second method, Fisher's exact test was used to test for significant association in the two-by-two tables of counts for virus $X$ and virus $Y$.

\section{RESULTS}

Virus incidence and spatial pattern in alfalfa. AMV, BYMV/ClYVV, and CMV were found in $100,76.9$, and $71.4 \%$, respectively, of the fields for which assays were done (Table 2). Virus incidence was more variable among fields than between years for AMV and CMV, but the reverse was found with BYMV/ClYVV (Table 3; covariance parameter estimates). Adjusted (for quadrat, field, and year variability) mean incidences of virus-infected plants showed that AMV was the most common of the viruses, with BYMV/ClYVV and CMV occurring at about the same incidence levels overall (Table 3). Aggregated spatial distributions of virus-infected plants were observed in 4 of 14 fields (Table 2).

Virus incidence and spatial pattern in snap bean. AMV and CMV were present in all 12 fields sampled in 2002, and BYMV/ClYVV in 10 fields (Table 1). In 2003, AMV, BYMV/ClYVV, and CMV were present in 8,9 , and 10 of 12 fields, respectively. Mean incidences of virusinfected plants were 26.0, 16.4, and $40.7 \%$ in 2002 and $1.5,4.3$, and $10.1 \%$ in 2003 for AMV, BYMV/CIYVV, and CMV, respectively. Virus incidence was less variable among fields compared with the variability among quadrats within fields (Table 4; see covariance parameter estimates), but the variance between years was 1.01 to
3.56 times higher than the variability among quadrats within fields. Modeladjusted (for the influences of quadrat, field, and year) mean incidences over all sampled fields were 6.66, 6.38, and $17.20 \%$ for AMV, BYMV/CIYVV, and CMV, respectively.

Aggregated patterns of virus-infected plants were observed in 8 of 12 fields in 2002 (Table 1). In 2003, there was evidence of aggregation of virus-infected snap bean plants in 5 of 12 fields (Table 1).

Effect of snap bean planting time and proximity to alfalfa on virus incidence. After accounting for the variability between years and among fields, there was no evidence that snap bean fields adjacent to alfalfa were at an increased risk of infection by any of the viruses we assayed for (Table 4). Late-planted fields were associated with higher incidences of AMV (3.74 versus $10.59 \%$ ) and BYMV/CIYVV (2.42 versus $13.57 \%$ ) when compared with early-planted fields. Within either early or late plantings, there were no differences in virus incidence between fields that were adjacent to or remote from alfalfa (Table 4).

Correlation between virus incidence in adjacent alfalfa and snap bean fields. For AMV, BYMV/ClYVV, and CMV there was no evidence of correlations (either positive or negative) between virus incidence in adjacent alfalfa and snap bean fields (Table 5; $P>0.10$ in all instances). In 2003, there were examples of snap bean fields with low virus incidence adjacent to alfalfa fields with a comparatively higher incidence of infected plants (e.g., AMV in
Buck and WCH fields). There also were instances of low incidences in alfalfa, but high incidences by comparison of the same virus in the adjacent snap bean fields (e.g., CMV in Buck fields).

Multiple infection and associations among viruses. In both alfalfa and snap bean fields, infection of plants by two or more viruses was observed (Tables 6 and 7 ), but was observed more frequently in the 2002 snap bean fields, partly reflecting the lower virus incidences observed in 2003. There was significant overdispersion in the number of viruses per plant $(D>1$, $P<0.05)$ in several snap bean fields in 2002 (Table 7), which indicated possible associations among viruses infecting plants. There were no such indications in 2003 based on dispersion statistics (Table 7).

Loglinear model fitting and Fisher's exact test indicated that there were significant positive associations $(P<0.05)$ between AMV and CMV in 10 of the 12 snap bean fields in 2002 (Table 8). There was no evidence of other associations (AMVBYMV/CIYVV or BYMV/ClYVV-CMV). No pairwise associations between viruses were detected in 2003 snap bean fields. Similarly, there were no pairwise associations between viruses in infected alfalfa plants in both years, except for a positive association between AMV and CMV in the Oak-Ala alfalfa field in 2002 (Table 8).

Molecular confirmation of AMV and CMV. Infection of alfalfa and snap bean by AMV and CMV in ELISA-positive samples was confirmed by IC RT-PCR amplification of a putative 750-bp AMV cp

Table 5. Correlation of virus incidence between adjacent alfalfa and snap bean fields

\begin{tabular}{lcccc}
\hline & \multicolumn{4}{c}{ Correlation coefficients $^{\mathbf{a}}$} \\
\cline { 2 - 5 } Virus $^{\mathbf{b}}$ & Pearson coefficient & $\boldsymbol{P}$ value & Spearman's coefficient & $\boldsymbol{P}$ value \\
\hline AMV & 0.354 & 0.259 & 0.288 & 0.365 \\
BYMV/CIYVV & 0.365 & 0.244 & 0.413 & 0.182 \\
CMV & -0.005 & 0.987 & 0.203 & 0.526 \\
\hline
\end{tabular}

${ }^{a}$ Coefficients were calculated for pooled incidence data from the 12 adjacent alfalfa and snap bean fields sampled over 2002 and 2003.

${ }^{\mathrm{b}} \mathrm{AMV}=$ Alfalfa mosaic virus; $\mathrm{BYMV/CIYVV}=$ Bean yellow mosaic virus, Clover yellow vein virus, or both; and CMV = Cucumber mosaic virus.

Table 4. Covariance parameter estimates and $P$ values for tests of the effects of planting time (pt) and proximity (prox) of snap bean fields to alfalfa on the incidence of viruses in bean plants sampled at the bloom stage

\begin{tabular}{|c|c|c|c|c|c|c|c|c|c|c|}
\hline \multirow[b]{2}{*}{ Virus $^{c}$} & \multicolumn{3}{|c|}{ Effect } & \multicolumn{4}{|c|}{ Contrast $^{\mathrm{a}}$} & \multicolumn{3}{|c|}{ Covariance parameter estimates ${ }^{b}$} \\
\hline & $p^{t^{d}}$ & prox $^{e}$ & pt $\times \operatorname{prox}^{f}$ & $\mathbf{E P} \mathbf{P}_{\mathbf{a}}-\mathbf{L} \mathbf{P}_{\mathbf{a}}$ & $\mathbf{E P}_{\mathbf{r}}-\mathbf{L} \mathbf{P}_{\mathbf{r}}$ & $\mathbf{E P} \mathbf{P}_{\mathrm{a}}-\mathbf{E} \mathbf{P}_{\mathrm{r}}$ & $\mathbf{L P} \mathbf{P}_{\mathrm{a}}-\mathbf{L} \mathbf{P}_{\mathrm{r}}$ & Year & Field & Quadrat \\
\hline AMV & 0.003 & 0.380 & 0.919 & 0.030 & 0.020 & 0.604 & 0.452 & 4.680 & 0.250 & 1.315 \\
\hline BYMV/ClYVV & $<0.001$ & 0.356 & 0.207 & 0.048 & 0.001 & 0.163 & 0.776 & 1.013 & 0.769 & 0.999 \\
\hline CMV & 0.736 & 0.655 & 0.648 & 0.932 & 0.574 & 0.995 & 0.526 & 2.595 & 1.460 & 1.288 \\
\hline Any & 0.100 & 0.898 & 0.488 & 0.475 & 0.102 & 0.690 & 0.557 & 2.138 & 0.909 & 1.316 \\
\hline
\end{tabular}

${ }^{a}$ Contrasts are between fields that were planted early (EP) or late (LP) in the season. Subscripts refer to whether fields were adjacent (a) or remote (r) from alfalfa.

${ }^{b}$ Estimates of the variance in incidence between the 2 years of sampling (2002 and 2003), variance among fields (24 fields over the 2 years), and the variance among sampled quadrats within fields (16 quadrats per field).

${ }^{\mathrm{c}} \mathrm{AMV}=$ Alfalfa mosaic virus; $\mathrm{BYMV} / \mathrm{ClYVV}=$ Bean yellow mosaic virus, Clover yellow vein virus, or both; $\mathrm{CMV}=$ Cucumber mosaic virus; and any = infection by any of the aforementioned viruses.

${ }^{\mathrm{d}}$ Early plantings were between late May and the first week in June and late plantings occurred during the first half of July.

e Snap bean fields were either adjacent to an alfalfa field or $>1 \mathrm{~km}$ from the nearest alfalfa field (remote).

${ }^{\mathrm{f}}$ Interaction term between pt and prox. 
gene fragment and a putative 650-bp CMV $\mathrm{cp}$ gene fragment. No amplifications were observed from virus-free plants grown in aphid-free greenhouses.

The NY-A and NY-B, AMV cp gene sequences were $99 \%$ similar, differing in only four nucleotides. According to BLAST searches of the GenBank nucleotide databases, NY-A and NY-B were $98 \%$ homologous with AMV strains ALALM5, MAARNA4, MAARNA3 L, and another AMV strain recently re- ported from Australia (GenBank accession no. AF332998). Nucleotide sequences were submitted to the NCBI GenBank database under accession numbers AY340070 (NY-A: alfalfa) and AY340071 (NY-B: bean).

Table 6. Incidence of multiple viruses per plant in alfalfa fields in 2002 and 2003

\begin{tabular}{|c|c|c|c|c|c|c|c|}
\hline \multirow[b]{2}{*}{ Year, field } & \multicolumn{4}{|c|}{ Number of plants with ${ }^{a}$} & \multicolumn{3}{|c|}{ Overdispersion test statistics ${ }^{b}$} \\
\hline & 0 viruses & 1 virus & 2 viruses & 3 viruses & $D$ & $\chi^{2}$ & $P$ value \\
\hline \multicolumn{8}{|l|}{2002} \\
\hline CY1 & 7 & 45 & 24 & 4 & 0.67 & 53.1 & 1.000 \\
\hline CY2 & 5 & 52 & 20 & 3 & 0.55 & 43.1 & 1.000 \\
\hline Kludt $^{\mathrm{c}}$ & 41 & 31 & 8 & $\ldots$ & 1.08 & 85.3 & 0.295 \\
\hline McCollum1 & 25 & 39 & 16 & 0 & 0.81 & 64.0 & 0.892 \\
\hline McCollum2 & 5 & 52 & 22 & 1 & 0.46 & 36.4 & 1.000 \\
\hline Oak-Ala & 48 & 23 & 8 & 1 & 1.23 & 96.9 & 0.084 \\
\hline Sentiff & 40 & 30 & 8 & 1 & 1.06 & 82.5 & 0.341 \\
\hline Torrey & 5 & 50 & 25 & 0 & 0.43 & 34.3 & 1.000 \\
\hline \multicolumn{8}{|l|}{2003} \\
\hline Asbury & 71 & 9 & 0 & 0 & n.a. & n.a. & n.a. \\
\hline Buck & 4 & 76 & 0 & 0 & n.a. & n.a. & n.a. \\
\hline $\mathrm{MC}$ & 76 & 4 & 0 & 0 & n.a. & n.a. & n.a. \\
\hline NB & 77 & 3 & 0 & 0 & n.a. & n.a. & n.a. \\
\hline Orch & 64 & 15 & 1 & 0 & 0.99 & 77.9 & 0.513 \\
\hline WCH & 0 & 50 & 30 & 0 & 0.32 & 25.2 & 1.000 \\
\hline
\end{tabular}

${ }^{a}$ Eighty plants sampled per field (20 quadrats, four plants per quadrat in 2002 and 16 quadrats, five plants per quadrat in 2003) were assayed for Alfalfa mosaic virus (AMV); Bean yellow mosaic virus, Clover yellow vein virus or both (BYMV/ClYVV); and Cucumber mosaic virus (CMV) by enzyme-linked immunosorbent assay.

${ }^{b}$ Number of viruses per plant is expected to follow a binomial distribution if there are no positive associations among the different viruses. Positive associations among viruses would inflate the variance in the number of viruses per plant above the binomial variance (i.e., overdispersion). The binary form of the index of dispersion $(D)$ is an indicator of possible overdispersion if $D>1(25)$. A chi-square test was done to formally test whether $D>1(25)$. $P$ values for the test are given. Dispersion statistics were not calculable for fields in which no sampled plants were positive for any of the viruses, or where they were not meaningful because of very low virus incidence (n.a. = not applicable).

${ }^{\mathrm{c}}$ Samples from Kludt were assayed for AMV and CMV only.

Table 7. Incidences of multiple viral infections per plant in snap beans at the bloom stage in 2002 and 2003

\begin{tabular}{|c|c|c|c|c|c|c|c|}
\hline \multirow[b]{2}{*}{ Year, field } & \multicolumn{4}{|c|}{ Number of plants with ${ }^{a}$} & \multicolumn{3}{|c|}{ Overdispersion test statistics $^{b}$} \\
\hline & 0 viruses & 1 virus & 2 viruses & 3 viruses & $D$ & $\chi^{2}$ & $P$ value \\
\hline \multicolumn{8}{|l|}{2002} \\
\hline $\mathrm{CY} 1$ & 63 & 8 & 7 & 2 & 1.81 & 143.0 & $<0.001$ \\
\hline CY2 & 31 & 30 & 15 & 4 & 1.23 & 97.1 & 0.081 \\
\hline Kelsey & 28 & 23 & 24 & 5 & 1.31 & 103.7 & 0.033 \\
\hline Kludt & 53 & 18 & 9 & 0 & 1.25 & 98.8 & 0.065 \\
\hline MB & 35 & 27 & 18 & 0 & 1.08 & 85.0 & 0.301 \\
\hline McCollum1 & 56 & 22 & 2 & 0 & 0.94 & 74.4 & 0.627 \\
\hline McCollum2 & 26 & 21 & 28 & 5 & 1.29 & 101.8 & 0.043 \\
\hline Mill & 48 & 20 & 10 & 2 & 1.40 & 110.9 & 0.010 \\
\hline Mix & 47 & 22 & 10 & 1 & 1.27 & 100.0 & 0.056 \\
\hline OakAla & 26 & 19 & 30 & 5 & 1.30 & 102.9 & 0.037 \\
\hline Sentiff & 9 & 15 & 40 & 16 & 1.11 & 87.7 & 0.235 \\
\hline Torrey & 31 & 34 & 14 & 1 & 0.99 & 78.0 & 0.512 \\
\hline \multicolumn{8}{|l|}{2003} \\
\hline Asbury & 74 & 5 & 1 & 0 & 1.25 & 98.7 & 0.066 \\
\hline BAT & 72 & 7 & 1 & 0 & 1.17 & 92.2 & 0.146 \\
\hline Buck & 43 & 36 & 1 & 0 & 0.69 & 54.9 & 1.000 \\
\hline Crick & 61 & 16 & 3 & 0 & 1.11 & 87.9 & 0.232 \\
\hline Gaines & 80 & 0 & 0 & 0 & n.a. & n.a. & n.a. \\
\hline MC & 64 & 16 & 0 & 0 & 0.87 & 68.6 & 0.793 \\
\hline NB & 69 & 11 & 0 & 0 & 0.92 & 72.3 & 0.689 \\
\hline Orch & 71 & 9 & 0 & 0 & 0.93 & 73.8 & 0.645 \\
\hline Perry & 74 & 6 & 0 & 0 & 0.96 & 75.9 & 0.578 \\
\hline WCH & 80 & 0 & 0 & 0 & n.a. & n.a. & n.a. \\
\hline Wood & 57 & 23 & 0 & 0 & 0.80 & 63.0 & 0.909 \\
\hline YG & 66 & 13 & 1 & 0 & 1.02 & 80.7 & 0.425 \\
\hline
\end{tabular}

${ }^{a}$ Eighty plants sampled per field (16 quadrats, five plants per quadrat) were assayed for Alfalfa mosaic virus (AMV); Bean yellow mosaic virus, Clover yellow vein virus, or both (BYMV/CIYVV); and Cucumber mosaic virus (CMV) by enzyme-linked immunosorbent assay.

${ }^{b}$ Number of viruses per plant is expected to follow a binomial distribution if there are no positive associations among the different viruses. Positive associations among viruses would inflate the variance in the number of viruses per plant above the binomial variance (i.e., overdispersion). The binary form of the index of dispersion $(D)$ is an indicator of possible overdispersion if $D>1$ (25). A chi-square test was done to formally test whether $D>1(25)$. $P$ values for the test are given. Dispersion statistics were not calculable for fields in which no sampled plants were positive for any of the viruses, or where they were not meaningful because of very low virus incidence (n.a. = not applicable). 


\section{DISCUSSION}

Processing snap bean crops in the Midwest and northeastern United States have suffered substantial yield and quality losses in recent years due to the effects of viruses (20). In both 2002 and 2003, we did observe virus-like symptoms (mainly chlorotic spotting, mosaic, and rugosity) on the foliage of some plants. In most instances, symptoms were either absent or impossible to associate unambiguously with any specific virus (those we assayed for or others). A further complication is that snap bean cultivars differ in their symptom expression to virus infection, as observed with CMV (10). For example, in 2002, we did not discern any symptoms while sampling the Kelsey field (cv. Igloo), but $52.5 \%$ of the plants were positive for CMV when assayed by ELISA. The cv. Igloo shows a reduction in leaf size upon infection with the CMV-Le strain (A. Taylor, personal communication), but no other foliar symptoms. Any reductions in leaf size were impossible to discern in the Kelsey field at the time of sampling, which illustrates the unreliability of visually assessing snap bean for quantitative determinations of virus incidence.

Aphidborne virus epidemics can be quite variable in magnitude over regions and seasons (16). We found the same with AMV, BYMV/CIYVV, and CMV in snap bean in 2002 and 2003. Infection by these aphid-transmitted viruses was prevalent in snap bean fields, but a striking feature was the variability in virus incidence between the 2 years. One key factor in aphidborne virus epidemics is the time of arrival of viruliferous aphids (16). In these same fields, alatae of 63 aphid species were identified (31), but the dominant species (up to sampling at bloom) were the pea aphid, corn leaf aphid (Rhopalosiphum maidis (Fitch)), and yellow clover aphid (Therioaphis trifolii (Monell)). The dominant species were different between years and even within the snap bean season. For example, the pea aphid and corn leaf aphid were prevalent in early-planted fields, whereas the yellow clover aphid was more common in late plantings. This suggests that one or a few species may be largely responsible for virus transmission to snap bean at any given time, as observed in other crops $(12,38,39)$.

The arrival of the soybean aphid $(24,40)$ coincidentally with virus epidemics in snap bean fields on a regional scale raised the hypothesis that the virus diseases were being spread by Aphis glycines. However, in 2002, no A. glycines alatae were trapped in either alfalfa or snap bean (31). In 2003, the mean cumulative number of $A$. glycines alatae per trap in late-planted snap bean was less than five by 19 August (31), and all bean fields were sampled by 21 August, by which time plants were at bloom stage. Thus, it is unlikely that A. glycines was a principal vector of virus spread observed in snap beans in 2003 up to the time the plants were sampled, though a relatively large number of A. glycines alatae were trapped in the following weeks (31). It is possible that A. glycines was responsible for further virus spread between bloom and sampling in 2003, but we did not assay any plants after bloom.

Table 8. Test statistics for the associations among viruses in snap beans and alfalfa, 2002 and 2003

\begin{tabular}{|c|c|c|c|c|c|c|}
\hline \multirow[b]{2}{*}{ Year, field } & \multicolumn{3}{|c|}{ 95\% Confidence interval for parameter ${ }^{\mathrm{a}}$} & \multicolumn{3}{|c|}{$P$ value (Fisher's exact test) ${ }^{b}$} \\
\hline & AMV-CMV & AMV-BYMV/CYVV & CMV-BYMV/CYVV & AMV-CMV & AMV-BYMV/CIYVV & CMV-BYMV/CIYVV \\
\hline \multirow{2}{*}{\multicolumn{7}{|c|}{$\begin{array}{l}\text { Snap bean } \\
2002\end{array}$}} \\
\hline & & & & & & \\
\hline CY1 & $(2.60,6.47)$ & $(-2.12,4.29)$ & $(-2.57,3.84)$ & $<0.001$ & 0.137 & 0.160 \\
\hline $\mathrm{CY} 2$ & $(0.65,3.53)$ & $(-2.05,0.75)$ & $(-0.22,1.79)$ & 0.004 & 0.767 & 0.140 \\
\hline Kelsey & $(1.53,4.21)$ & $(-1.80,0.93)$ & $(-0.88,1.69)$ & $<0.001$ & 0.736 & 0.479 \\
\hline Kludt $^{\mathrm{c}}$ & n.a. & n.a. & n.a. & 0.002 & n.a. & n.a. \\
\hline MB & $(0.69,2.78)$ & $(-3.39,1.02)$ & $(-3.49,0.91)$ & $<0.001$ & 0.986 & 0.988 \\
\hline McCollum $1^{c}$ & n.a. & n.a. & n.a. & 0.087 & n.a. & n.a. \\
\hline McCollum2 & $(1.90,5.16)$ & $(-0.72,3.62)$ & $(-3.11,1.26)$ & $<0.001$ & 0.226 & 0.627 \\
\hline Mill & $(1.14,4.39)$ & $(-1.63,2.28)$ & $(-0.96,2.36)$ & $<0.001$ & 0.344 & 0.232 \\
\hline Mix & $(0.65,2.91)$ & $(-2.09,3.27)$ & $(-2.73,2.62)$ & 0.002 & 0.540 & 0.663 \\
\hline OakAla & $(1.46,3.83)$ & $(-2.34,0.19)$ & $(-0.27,2.14)$ & $<0.001$ & 0.908 & 0.304 \\
\hline Sentiff & $\ldots^{\mathrm{d}}$ & $(-1.67,0.29)$ & $(-0.12,2.89)$ & $<0.001$ & 0.816 & 0.134 \\
\hline Torrey & $(-0.03,2.24)$ & $(-2.55,0.18)$ & $(-1.08,1.22)$ & 0.051 & 0.984 & 0.705 \\
\hline \multicolumn{7}{|l|}{2003} \\
\hline Asburye & $\ldots$ & $\ldots$ & $\ldots$ & n.a. ${ }^{f}$ & 0.063 & n.a. ${ }^{f}$ \\
\hline $\mathrm{BAT}^{\mathrm{e}}$ & $\ldots$ & $\ldots$ & $\ldots$ & 0.088 & n.a. ${ }^{f}$ & n.a. ${ }^{f}$ \\
\hline Buck $^{\mathrm{e}}$ & $\ldots$ & $\ldots$ & $\ldots$ & 0.450 & n.a. ${ }^{f}$ & n.a. ${ }^{f}$ \\
\hline Crick & $(-1.17,3.85)$ & $\ldots{ }^{d}$ & $(-0.83,2.69)$ & 0.362 & n.a. ${ }^{f}$ & 0.302 \\
\hline $\mathrm{YG}^{\mathrm{e}}$ & $\ldots$ & $\ldots$ & $\ldots$ & n.a. ${ }^{\mathrm{f}}$ & 0.350 & n.a. ${ }^{\mathrm{f}}$ \\
\hline Alfalfa & & & & & & \\
\hline \multicolumn{7}{|l|}{2002} \\
\hline CY1 & $(-2.66,1.90)$ & $(-0.75,2.54)$ & $(-0.56,2.63)$ & 0.790 & 0.245 & 0.190 \\
\hline CY2 & $(-1.60,1.78)$ & $(-2.54,1.95)$ & $(-0.94,2.12)$ & 0.650 & 0.820 & 0.350 \\
\hline Kludt $^{c}$ & n.a. & n.a. & n.a. & 0.190 & n.a. & n.a. \\
\hline McCollum1 & $(-1.44,0.54)$ & $(-0.83,1.91)$ & $(-3.56,0.71)$ & 0.899 & 0.276 & 0.978 \\
\hline McCollum2 & $(-1.51,2.86)$ & $(-2.86,0.73)$ & $(-3.01,1.31)$ & 0.422 & 0.958 & 0.913 \\
\hline OakAla & $(-1.25,4.33)$ & $(-4.32,0.45)$ & $(-0.59,2.87)$ & $<0.001$ & 0.139 & 0.446 \\
\hline Sentiff & $(-1.72,1.06)$ & $(-0.93,1.68)$ & $(-0.93,1.68)$ & 0.774 & 0.409 & 0.409 \\
\hline Torrey ${ }^{e}$ & $\ldots$ & $\ldots$ & $\ldots$ & 0.769 & 0.208 & 1.000 \\
\hline \multicolumn{7}{|l|}{2003} \\
\hline Orch $^{e}$ & $\ldots$ & $\ldots$ & $\ldots$ & 1.000 & 1.000 & 0.453 \\
\hline $\mathrm{WCH}^{\mathrm{e}}$ & $\ldots$ & $\ldots$ & $\ldots$ & 1.000 & 0.910 & 0.875 \\
\hline
\end{tabular}

${ }^{a}$ The $95 \%$ confidence intervals for the pairwise interaction parameters in a loglinear model relating counts of infected plants to virus incidence. If the confidence interval includes zero, then there is no evidence of an association. Positive associations are indicated when the confidence interval is on the positive side of the real number line; $x-y$ represents the pairwise interaction between virus $x$ and virus $y$. AMV $=$ Alfalfa mosaic virus; BYMV/ClYVV $=$ Bean yellow mosaic virus, Clover yellow vein virus, or both; and $\mathrm{CMV}=$ Cucumber mosaic virus; $\mathrm{n} . \mathrm{a} .=$ not applicable.

${ }^{\mathrm{b}}$ Fisher's exact test for independence in two-by-two tables. Positive association between the virus pair $x-y$ is indicated when $P<0.05$.

${ }^{\mathrm{c}}$ BYMV/ClYVV was not detected in McCollum1 and Kludt snap bean fields, and was not tested for in samples from the Kludt alfalfa field. The loglinear model, as well as Fisher's exact tests involving BYMV/CIYVV, were not applicable (n.a.).

d Standard error for the estimated parameter was zero.

${ }^{e}$ Loglinear model could not be fit or did not converge because of relatively low virus incidences.

${ }^{\mathrm{f}}$ Fisher's exact test not applicable (n.a.) because there were no cases of infection by both viruses of the $x-y$ pair. 
A second key factor in aphidborne virus epidemics is source magnitude (16). Source magnitude is a function of virus incidence, field size, and plant density in the field. Because alfalfa is a high-density, major acreage crop in western New York, we hypothesized that proximity to alfalfa would increase the risk of virus infection in snap bean. All viruses (AMV, $\mathrm{BYMV} / \mathrm{ClYVV}$, and CMV) were prevalent in alfalfa, but the mean incidence of AMV was six times higher than the mean incidence of either BYMV/ClYVV or CMV. There was a marked variability in virus incidence among alfalfa fields for AMV and CMV. We found no evidence for an increased risk of virus infection in snap bean adjacent to alfalfa among the fields surveyed in 2002 and 2003; nor was there a correlation between virus incidence in alfalfa and adjacent snap bean. Of the dominant aphid species trapped (31), alfalfa is not a host for A. glycines or $R$. maidis, but it is colonized by Acyrthosiphon pisum and $T$. trifolii. There were no differences in abundance or temporal patterns of aphid dispersal between alfalfa and adjacent snap bean fields and dispersal rates were relatively constant without marked periods of sudden increases (31). This suggests that alatae are dispersing equally to alfalfa and adjacent snap bean (not en masse from alfalfa to adjacent snap bean), and is supported by the evidence from the virus assays. For example, the WCH snap bean field was adjacent to an alfalfa field with incidences of infection of $58.8 \%$ by AMV and $72.5 \%$ by CMV, yet none of the snap bean plants sampled at bloom were positive for virus infection. The same pattern was seen with AMV in the Buck adjacent snap bean and alfalfa fields. In the same Buck fields, no alfalfa samples tested positive for CMV, yet $42.5 \%$ of plants in the adjacent snap bean field were positive for CMV. It appears that alatae are dispersing over distances of several kilometers (31). Nevertheless, prevalence of aphid-transmitted viruses in alfalfa, combined with its large acreage, does strongly suggest this crop being a risk factor for virus epidemics in snap bean.

Among the viruses we tested for in snap bean, the mean incidence of CMV was the highest, which is of concern because CMV can negatively impact bean pod quality and yield $(14,37,51)$. Moreover, we found that the risk of CMV infection was the same for early- and late-planted snap bean. The risk of infection by AMV was higher in late-season snap bean compared with the earlier plantings, and co-infection of plants by $A M V$ and CMV was significant in 10 snap bean fields (all in 2002). However, experiments done in Wisconsin demonstrated that snap bean plants co-infected with AMV and CMV did not show more severe foliar symptoms than plants inoculated with CMV alone (10). Preliminary tests done in New York and Wisconsin on commercially available snap bean cultivars found that none were immune to CMV (10). In the long term, attempts are being made in New York to develop CMVresistant snap bean cultivars from interspecific crosses between snap bean and scarlet runner bean (11). Short-term strategies such as reflective mulches (47), row covers (50), and mineral oils (29) have been used successfully in some vegetable crops to manage aphid vectors in order to reduce or delay infection by viruses. Unfortunately, these strategies are not practical for growers in the Northeast when one considers the margin of return on snap bean. Isolating susceptible crops from known virus sources is another recommended strategy for reducing the incidence of virus infection (49). However, it is not likely that this strategy should work, because our study demonstrated that isolation from putative sources of viruses (alfalfa) did not decrease the risk of virus infection. Similarly, biological control is not a practical strategy for managing viruses in snap bean because viruliferous, noncolonizing aphids spread nonpersistent viruses within a matter of seconds. Faced with no other alternative, some snap bean growers in New York have been applying organophosphates, carbamates, and pyrethroids in the hope of killing aphids before they spread viruses (B. A. Nault, personal observation). This strategy does not work against viruses spread in a nonpersistent manner $(35,48)$.

In the short and intermediate term, identifying tolerance to aphid-transmitted viruses in existing commercial cultivars and the effective deployment of those cultivars within current planting schedules is the most promising solution. Nearly $90 \%$ of the processing snap bean acreage in New York is devoted to large round green beans (= large sieve size), whereas the remainder is a mix of medium and small whole green beans (= medium to small sieve sizes) and yellow and wax beans of all sizes (M. Gardinier, personal communication). Processors predetermine planting schedules and cultivars before the season begins and growers typically plant multiple cultivars over the season. Although growers are willing to replace a virus-sensitive cultivar with a virus-tolerant cultivar, the replacement must be within the same-sized snap bean (i.e., substitute one large round green bean cultivar with another, but not with a medium or small bean). Another important consideration that affects the substitution of a virus-sensitive cultivar for one that is tolerant is that processors strongly prefer specific cultivars (even though they are virus sensitive) because they have superior characteristics for processing. Consequently, widespread abandonment of virussensitive cultivars is highly unlikely.

Our study provides a useful baseline on the status of virus infection in snap bean in New York over a 2-year period following the first major epidemics in the Northeast and Midwest. The data we present in this article are only a preliminary step in elucidating the biology of virus epidemics in snap bean. Further experiments are needed to determine the virus transmission efficiencies of the major aphid species found in snap bean. Information also is needed on the relationship between vector activity and the temporal progression of virus infection in commercial fields. The role of alfalfa and other large-acre forages as virus sources needs to be clarified. One approach is to verify whether the viruses can infect snap bean after mechanical inoculation with virus-infected alfalfa sap. On another level, IC RT-PCR and nucleotide sequence analysis can be extended beyond corroborating serological results to quantifying the similarity between virus populations (or quasipopulations) in alfalfa and snap bean (3). Multiple viruses per plant appears to be common (10; this study); therefore, multiplex RT-PCR as developed for other plant virus-crop systems (43) would be of valuable assistance in snap bean virus epidemiology. Finally, tolerant cultivars need to be identified. Then, these pieces of information must be integrated into a strategy to best mitigate virus spread in snap bean. If successful, a similar approach may prove useful for the management of aphid-transmitted viruses in other legume crops such as soybean and dry bean.

\section{ACKNOWLEDGMENTS}

This research was supported by grants to B. A Nault from the New York Vegetable Research Council and Association. We thank A. McFaul for help in identifying the fields sampled in this study; K. Straight for help in the processing of samples; and C. Saeli, J. Scarcelli, L. Staples, and S. Caito II for their assistance with the serological assays and molecular characterization studies.

\section{LITERATURE CITED}

1. Agresti, A. 1996. An Introduction to Categorical Data Analysis. Wiley, New York.

2. Altschul, S. F., Madden, T. L., Schaffer, A. A., Zhang, J. H., Zhang, Z., Miller, W., and Lipman, D. J. 1997. Gapped BLAST and PSI-BLAST: a new generation of protein database search programs. Nucleic Acids Res. 25:3389-3402.

3. Bousalem, M., Dallot, S., and Guyader, S. 2000. The use of phylogenetic data to develop molecular tools for the detection and genotyping of Yam mosaic virus. Potential application in molecular epidemiology. J. Virol. Methods 90:25-36.

4. Burke, D. W. 1963. Incidence of viruses infectious to beans in plants of twelve alfalfa varieties. Plant Dis. Rep. 47:845-847.

5. Choi, J. K., Ryu, K. H., Park, W. M., Kim, S. J., and Mok, W. 1995. Rapid detection and identification of cucumber mosaic virus by reverse transcription and polymerase chain reaction (RT-PCR) and restriction analysis. J. Plant Biol. 38:267-274.

6. Clark, M. F., and Adams, A. N. 1977. Characteristics of the microplate method of enzymelinked immunosorbent assay for the detection of plant viruses. J. Gen. Virol. 34:475-483.

7. Coutts, B. A., and Jones, R. A. C. 2002. Temporal dynamics of spread of four viruses within mixed species perennial pastures. Ann. Appl. Biol. 140:37-52. 
8. Doolittle, S. P., and Zaumeyer, W. J. 1953. A pepper ringspot caused by strains of cucumber mosaic virus from pepper and alfalfa. Phytopathology 43:333-337.

9. Frosheiser, F. I. 1964. Prevalence of alfalfa mosaic virus in alfalfa in Minnesota. Plant Dis. Rep. 48:506-507.

10. Grau, C. R., Stevenson, W. R., and Mondjana, A. M. 2002. Viruses causing losses on processing beans in the Midwest. Proc. 2002 Wis. Fertilizer, Aglime, and Pest Manage. Conf. 41:248-256.

11. Griffiths, P. D. 2004. Breeding for resistance to viruses in snap beans. Pages 146-147 in: Proc. 2004 Empire State Fruit and Vegetable Expo. Cornell Cooperative Extension, Rochester, NY.

12. Halbert, S. E., Irwin, M. E., and Goodman, R. M. 1981. Alate aphid (Homoptera:Aphididae) species and their relative importance as field vectors of soybean mosaic virus. Ann. Appl. Biol. 97:1-9.

13. Hampton, R. O. 1967. Natural spread of viruses infectious to beans. Phytopathology 57:476-481.

14. Horvath, J. 1983. The role of some plants in the ecology of cucumber mosaic virus with special regard to bean. Acta Phytopathol. Acad. Sci. Hung. 18:217-224.

15. Hughes, G., and Madden, L. V. 1992. Aggregation and incidence of disease. Plant Pathol. 41:657-660.

16. Jones, R. A. C. 2001. Developing integrated disease management strategies against nonpersistently aphid-borne viruses: a model programme. Integr. Pest Manage. Rev. 6:15-46.

17. Jones, R. A. C. 2005. Patterns of spread of two non-persistently aphid-borne viruses in lupin stands under four different infection scenarios. Ann. Appl. Biol. 146:337-350.

18. Larsen, R. C., and Eastwell, K. C. 2004. Identification of Clover yellow vein virus as the causal agent of pod necrosis ("chocolate pod") in snap bean. (Abstr.) Phytopathology 94:S57.

19. Larsen, R. C., and Eastwell, K. C. 2004. A PCR-based assay for differentiation of clover yellow vein virus and bean yellow mosaic virus in common bean. Annu. Rep. Bean Improv. Coop. 47:123-124.

20. Larsen, R. C., Miklas, P. N., Eastwell, K. C., Grau, C. R., and Mondjana, A. 2002. A virus disease complex devastating late season snap bean production in the Midwest. Annu. Rep. Bean Improv. Coop. 45:36-37.

21. Ling, K.-S., Zhu, H.-Y., Petrovic, N., and Gonsalves, D. 2001. Comparative effectiveness of ELISA and RT-PCR for detecting grapevine leafroll associated closterovirus-3 in field samples. Am. J. Enol. Vitic. 52:21-27.

22. Littell, R. C., Milliken, G. A., Stroup, W. W., and Wolfinger, R. D. 1996. SAS System for Mixed Models. SAS Institute. Cary, NC.

23. Losey, J. E., and Eubanks, M. D. 2000. Implications of pea aphid host-plant specialization for the potential colonization of vegetables following post-harvest emigration from forage crops. Environ. Entomol. 29:1283-1288.

24. Losey, J. E., Waldron, J. K., Hoebeke, E. R., Macomber, L. E., and Scott, B. N. 2002. First record of the soybean aphid, Aphis glycines Matsumura (Hemiptera: Sternorrhyncha: Aphididae), in New York. Great Lakes Entomol. 35:101-105.

25. Madden, L. V., and Hughes, G. 1995. Plant disease incidence: Distribution, heterogeneity, and temporal analysis. Annu. Rev. Phytopathol. 33:529-564.

26. Madden, L. V., and Hughes, G. 1999. Sampling for plant disease incidence. Phytopathology 89:1088-1103.

27. Madden, L. V., Pirone, T. P., and Raccah, B. 1987. Analysis of spatial patterns of virusdiseased tobacco plants. Phytopathology 77:1409-1417.

28. Madden, L. V., Turechek, W. W., and Nita, M. 2002. Evaluation of generalized linear mixed models for analyzing disease incidence data obtained in designed experiments. Plant Dis. 86:316-325.

29. Martin, B., Varela, I., and Cabaleiro, C. 2004. Effects of various oils on survival of Myzus persicae Sulzer and its transmission of cucumber mosaic virus on pepper. J. Horticult. Sci. Biotechnol. 79:855-858.

30. McLaughlin, M. R., and Boykin, D. L. 1988. Virus diseases of seven species of forage legumes in the southeastern United States. Plant Dis. 72:539-542.

31. Nault, B. A., Shah, D. A., Dillard, H. R., and McFaul, A. C. 2004. Seasonal and spatial dynamics of alate aphid dispersal in snap bean fields in proximity to alfalfa and implications for virus management. Environ. Entomol. 33:1593-1601.

32. Nault, L. R. 1997. Arthropod transmission of plant viruses: A new synthesis. Ann. Entomol. Soc. Am. 90:521-541.

33. Ofir, M., Gross, Y., Bangerth, F., and Kigel, J. 1993. High temperature effects on pod and seed production as related to hormone levels and abscission of reproductive structures in common bean (Phaseolus vulgaris L.). Sci. Hortic. 55:201-211.

34. Parrella, G., Lanave, C., Marchoux, G., Sialer, M. M. F., Di Franco, A., and Gallitelli, D. 2000. Evidence for two distinct subgroups of Alfalfa mosaic virus (AMV) from France and Italy and their relationships with other AMV strains. Arch. Virol. 145:2659-2667.

35. Perring, T. M., Gruenhagen, N. M., and Farrar, C. A. 1999. Management of plant viral diseases through chemical control of insect vectors. Annu. Rev. Entomol. 44:457-481.

36. Porch, T. G., and Jahn, M. 2001. Effects of high-temperature stress on microsporogenesis in heat-sensitive and heat-tolerant genotypes of Phaseolus vulgaris. Plant Cell En- viron. 24:723-731.

37. Provvidenti, R. 1976. Reaction of Phaseolus and Macroptilium species to a strain of cucumber mosaic virus. Plant Dis. Rep. 60:289293.

38. Raccah, B. 1986. Nonpersistent virusesepidemiology and control. Adv. Virus Res. 31:387-429

39. Raccah, B., Gal-on, A., and Eastop, V. F. 1985. The role of flying aphid vectors in the transmission of cucumber mosaic virus and potato virus $\mathrm{Y}$ to peppers in Israel. Ann. Appl. Biol. 106:451-460.

40. Ragsdale, D. W., Voegtlin, D. J., and O'Neil, R. J. 2004. Soybean aphid biology in North America. Ann. Entomol. Soc. Am. 97:204-208.

41. Rahman, F., and Peaden, R. N. 1993. Incidence of viruses on alfalfa in western North America. Plant Dis. 77:160-162.

42. Sambrook, J., Fritsch, E. F., and Maniatis, T. A. 1989. Molecular Cloning: A Laboratory Manual. 2nd ed. Cold Spring Harbor Laboratory Press, Cold Spring Harbor, NY.

43. Sanchez-Navarro, J. A., Aparicio, F., Herranz, M. C., Minafra, A., Myrta, A., and Pallas, V. 2005. Simultaneous detection and identification of eight stone fruit viruses by one-step RTPCR. Eur. J. Plant Pathol. 111:77-84.

44. Scott, S. W., McLaughlin, M. R., and Ainsworth, A. J. 1989. Monoclonal antibodies produced to bean yellow mosaic virus, clover yellow vein virus, and pea mosaic virus which cross-react among the three viruses. Arch. Virol. 108:161-167.

45. Stoltz, R. L., and McNeal, C. D., Jr. 1982. Assessment of insect emigration from alfalfa hay to bean fields. Environ. Entomol. 11:578580 .

46. Stuteville, D. L., and Erwin, D. C. 1990. Compendium of Alfalfa Diseases. 2nd ed. American Phytopathological Society Press, St. Paul, MN.

47. Summers, C. G., Mitchell, J. P., and Stapleton, J. J. 2004. Management of aphid-borne viruses and Bemisia argentifolii (Homoptera: Aleyrodidae) in zucchini squash by using UV reflective plastic and wheat straw mulches. Environ. Entomol. 33:1447-1457.

48. Thackray, D. J., Jones, R. A C , Bwye, A. M. and Coutts, B. A. 2000. Further studies on the effects of insecticides on aphid vector numbers and spread of cucumber mosaic virus in narrow-leafed lupins (Lupinus angustifolius) Crop Prot. 19:121-139.

49. Thresh, J. M. 1976. Gradients of plant virus diseases. Ann. Appl. Biol. 82:381-406.

50. Webb, S. E., and Linda, S. B. 1992. Evaluation of spunbonded polyethylene row covers as a method of excluding insects and viruses affecting fall-grown squash in Florida. J. Econ. Entomol. 85:2344-2352.

51. Whipple, O. C., and Walker, J. C. 1941. Strains of cucumber mosaic virus pathogenic on bean and pea. J. Agric. Res. 62:27-60. 